\title{
Sintesis dan Luas Permukaan Padatan $\mathrm{Mg}_{1-\mathrm{x}} \mathrm{Cu}_{\mathrm{x}} \mathrm{F}_{1,985} \mathrm{OH}_{0,015}$
}

\author{
Gathut Mawahyu Jatmiko dan Irmina Kris Murwani \\ Departemen Kimia, Fakultas Matematika dan Ilmu Pengetahuan Alam, Institut Teknologi Sepuluh Nopember \\ (ITS) \\ e-mail:irmina@chem.its.ac.id
}

\begin{abstract}
Abstrak-Pada penelitian ini telah dilakukan sintesis padatan $\mathrm{Mg}_{1-\mathrm{x}} \mathrm{Cu}_{\mathrm{x}} \mathrm{F}_{1,985} \mathrm{OH}_{0,015}(\mathrm{x}=0 ; 0,025 ; 0,05 ; 0,075 ;$ dan 0,1$)$ dengan metode sol-gel. Padatan diukur luas permukaannya dengan adsorpsi gas $\mathrm{N}_{2}$. Hasil pengukuran luas permukaan padatan berkisar antara 30,358 hingga $42,812 \mathrm{~m}^{2} / \mathrm{g}$. Modifikasi doping logam $\mathrm{Cu}$ pada $\mathrm{MgF}_{1,985} \mathrm{OH}_{0,015}$ dapat mempengaruhi luas permukaan padatan. Luas permukaan tertinggi diperoleh pada padatan $\mathrm{Mg}_{0,950} \mathrm{Cu}_{0,050} \mathrm{~F}_{1,985} \mathrm{OH}_{0,015}$ yakni sebesar 42,812 $\mathrm{m}^{2} / \mathrm{g}$.
\end{abstract}

Kata Kunci- $\mathrm{Mg}_{1-x} \mathrm{Cu}_{x} \mathrm{~F}_{1,985} \mathrm{OH}_{0,015}$, Luas Permukaan, Metode Sol-Gel, doping.

\section{PENDAHULUAN}

L OGAM tembaga $(\mathrm{Cu})$ merupakan salah satu logam transisi yang keberadaan di alam sangat melimpah dan sudah banyak dimanfaatkan dalam dunia industri dan sains. Tembaga memiliki sifat keasaman Lewis yang relatif tinggi dan dapat digunakan sebagai padatan yang memiliki sifat keasaman. Beberapa padatan dari logam $\mathrm{Cu}$ sudah mulai dikembangkan [1]. $\operatorname{MgF}_{2-\mathrm{x}}(\mathrm{OH})_{\mathrm{x}}$ dengan $0 \leq \mathrm{x} \leq 0$ merupakan padatan memiliki keasaman sedang dan stabilitas termal yang tinggi [2].

Sol-gel merupakan salah satu metode sintesis material berpori dengan metode basah, karena pada prosesnya melibatkan larutan sebagai medianya [3]. Metode sol-gel sangat menjanjikan karena prosesnya sederhana, fleksibel, murah dan konsumsi energinya rendah [4]. Metode sol-gel juga menawarkan pengontrolan karakter volume pori, distribusi ukuran pori serta permukaan padatan yang baik [5]. Doping merupakan suatu metode modifikasi padatan dengan logam-logam aliovalent. Peningkatan keasaman lewis dengan doping kation aliovalent sebelumnya telah diteliti oleh Tanabe, dkk. pada tahun 1974 dan dikembangkan pada persenyawaan fluorida oleh Kemnitz, dkk. pada tahun 2002[6][7]. Kombinasi antara metode doping padatan dengan metode sol-gel dapat menjadi alternatif pengontrolan stabilitas, karakter volume dan distribusi pori padatan. Selain itu, proses sintesisnya akan lebih sederhana, fleksibel dan murah.. Metode doping logam juga diharapkan dapat meningkatkan sisi aktif dari padatan dan luas permukaan padatan. Oleh karena itu dilakukan doping logam $\mathrm{Cu}$ pada $\mathrm{MgF}_{1,985}(\mathrm{OH})_{0,015}$ dan dilakukan variasi mol $\mathrm{Cu}$ untuk mengetahui mol optimum doping logam sebagai padatan. Pengukuran luas permukaan padatan dengan adsorpsi gas $\mathrm{N}_{2}$ dilakukan agar diketahui luas permukaan dari padatan yang telah disintesis.

\section{URAIAN PENELITIAN}

\section{A. Alat dan Bahan}

\section{1) Alat}

Peralatan yang digunakan pada penelitian ini terbagi menjadui dua, yaitu peralatan sederhana dan instrumen. Peralatan sederhana yang digunakan meliputi peralatan yang terbuat dari polietilen dan gelas. Instrumen yang dipakau meliputi oven, furnace, adsorpsi gas $\mathrm{N}_{2}$ Micromeritics ASAP 2020.

2) Bahan

Bahan yang digunakan dalam penelitian ini merupakan bahan kimia yang memiliki kemurnian tinggi atau disebut dengan pro analisis (p.a) yakni magnesium turnings (Sigma Aldrich, 99,98\%); Tembaga (II) Asetat Monohidrat (Merck); Metanol (Merck); HF (Merck).

\section{B. Prosedur Kerja}

1) Sintesis Padatan $\mathrm{MgF}_{1,985} \mathrm{OH}_{0,015}$

Sintesis padatan $\mathrm{MgF}_{1,985}(\mathrm{OH})_{0,015}$ diawali dengan pembuatan $\mathrm{Mg}\left(\mathrm{OCH}_{3}\right)_{2}$ melalui reaksi antara $\mathrm{Mg}$ turnings dan metanol hingga terbentuk suspensi. Kemudian hasil reaksi yang berupa suspensi tersebut diaduk dengan magnetic stirrer dan dilakukan refluks hingga terbentuk emulsi putih. Asam fluorida ditambahkan ke dalam emulsi putih sambil diaduk hingga terbentuk sol homogen. Sol diaduk terus menerus pada suhu ruang hingga terbentuk gel. Gel kemudian diperam pada suhu ruang hingga terbentuk gel stabil. Kemudian gel dikeringkan dan dikalsinasi.

2) Sintesis Padatan $\mathrm{Mg}_{1-x} \mathrm{Cu}_{x} \mathrm{~F}_{1,985} \mathrm{OH}_{0,015}$

Sintesis padatan $\mathrm{Mg}_{1-\mathrm{x}} \mathrm{Cu}_{\mathrm{x}} \mathrm{F}_{1,985}(\mathrm{OH})_{0,015}$ dengan $\mathrm{x}=0,025$; 0,$05 ; 0,075$; dan 0,1 dilakukan dengan cara yang sama dengan sintesis $\mathrm{MgF}_{1,985}(\mathrm{OH})_{0,015}$, hanya sebelum ditambahkan larutan HF, ditambahkan terlebih dahulu larutan $\mathrm{Cu}^{2+}$ sesuai dengan kebutuhan. Kemudian dilakukan pemanasan kondisi refluks. Selanjutnya, ditambahkan HF sedikit demi sedikit sesuai perhitungan stoikiometri, diaduk dengan magnetic stirrer hingga terbentuk sol yang homogen. Tahap berikutnya sama dengan tahapan sintesis $\mathrm{MgF}_{1,985}(\mathrm{OH})_{0,015}$ hingga didapatkan serbuk yang siap dikarakterisasi lebih lanjut.

3) Pengukuran Luas Permukaan Padatan dengam Adsorpsi Gas $\mathrm{N}_{2}$

Padatan yang telah diperoleh yaitu $\mathrm{Mg}_{1-\mathrm{x}} \mathrm{Cu}_{\mathrm{x}} \mathrm{F}_{1,985}(\mathrm{OH})_{0,015}$ diukur luas permukaannya dengan adsorpsi gas $\mathrm{N}_{2}$. Pengukuran dilakukan pada suhu $77 \mathrm{~K}$ dalam keadaan vakum. Padatan $\mathrm{Mg}_{1-\mathrm{x}} \mathrm{Cu}_{\mathrm{x}} \mathrm{F}_{1,985}(\mathrm{OH})_{0,015}$ di-degassing dengan $\mathrm{N}_{2}$ pada laju alir $30 \mathrm{~cm}^{3} /$ menit dan suhu $300^{\circ} \mathrm{C}$ selama 3 jam, kemudian dianalisis BET full isotermis. 


\section{HASIL DAN PEMBAHASAN}

\section{A. Padatan $\mathrm{MgF1}, 985(\mathrm{OH}) 0,015$ \\ Mg1-xCuxF1,985(OH)0,015}

dan

Sintesis padatan $\mathrm{MgF}_{1,985}(\mathrm{OH})_{0,015}$ dalam penelitian ini dilakukan dengan metode sol-gel. Menurut Perego dan Villa, metode sol-gel menawarkan pengontrolan karakter volume pori, distribusi ukuran pori serta permukaan padatan yang baik [5]. Metode sintesis ini diadopsi dari penelitian yang telah dilakukan oleh Wuttke dkk. [8].

Tahapan pertama adalah pembentukan logam alkoksida, dalam penelitian ini logam alkoksida yang dimaksud adalah $\mathrm{Mg}\left(\mathrm{OCH}_{3}\right)_{2}$. Kemudian pada logam alkoksida tadi ditambahkan larutan HF dan diaduk dengan magnetic stirrer hingga terbentuk sol, pengadukan dilanjutkan hingga terbentuk gel. Gel yang terbentuk kemudian diperam hingga didapatkan gel stabil. Selanjutnya, gel stabil dikeringkan dan dikalsinasi pada suhu $400{ }^{\circ} \mathrm{C}$.

Proses sintesis padatan $\mathrm{Mg}_{1-\mathrm{x}} \mathrm{Cu}_{\mathrm{x}} \mathrm{F}_{0,985}(\mathrm{OH})_{0,015}$ hampir sama dengan proses sintesis padatan $\mathrm{MgF}_{0,985}(\mathrm{OH})_{0,015}$. Perbedaannya terdapat pada penambahan dopant yang berupa larutan tembaga metoksida sesaat setelah emulsi putih $\mathrm{Mg}\left(\mathrm{OCH}_{3}\right)_{2}$ terbentuk. Tujuan modifikasi doping logam adalah adanya peningkatan luas permukaan padatan [9]. Setelah dilakukannya penambahan larutan $\mathrm{Cu}\left(\mathrm{OCH}_{3}\right)_{2}$, emulsi putih berubah warna menjadi biru kental. Terbentuknya campuran biru kental ini menandakan terdapat $\mathrm{Cu}\left(\mathrm{OCH}_{3}\right)_{2}$ dalam emulsi $\mathrm{Mg}\left(\mathrm{OCH}_{3}\right)_{2}$. Tahap selanjutnya sama dengan sintesis padatan $\mathrm{MgF}_{0,985}(\mathrm{OH})_{0,015}$.

Tabel 1.

Data Luas Permukaan Padatan $\mathrm{Mg}_{1-\mathrm{x}} \mathrm{Cu}_{\mathrm{x}} \mathrm{F}_{0,985}(\mathrm{OH})_{0,015}$

\begin{tabular}{cc}
\hline \hline Nilai $\mathrm{x}$ & Luas Permukaan $\left(\mathrm{m}^{2} / \mathrm{g}\right)$ \\
\hline 0 & 30,358 \\
0,025 & 40,214 \\
0,05 & 42,812 \\
0,075 & 40,989 \\
0,1 & 41,678 \\
\hline \hline
\end{tabular}

Gel stabil berwarna hijau toska akan diperoleh setelah pemeraman gel basah selama beberapa hari. Kemudian gel stabil dikeringkan vakum untuk menghilangkan pelarut. Setelah itu padatan di kalsinasi pada suhu $400{ }^{\circ} \mathrm{C}$ Hasil dari proses kalsinasi pada suhu $400{ }^{\circ} \mathrm{C}$ adalah serbuk padatan yang berwarna coklat. Semakin tinggi nilai konsentrasi $\mathrm{Cu}$ maka semakin pekat intensitas warna padatan yang dihasilkan. Padatan yang terbentuk kemudian dikarakterisasi luas permukaannya dengan adsorpsi gas $\mathrm{N}_{2}$ Micromeritics ASAP 2020.

\section{B. Luas Permukaan Padatan}

Pada penelitian ini, padatan $\mathrm{Mg}_{1-\mathrm{x}} \mathrm{Cu}_{\mathrm{x}} \mathrm{F}_{0,985}(\mathrm{OH})_{0,015}(\mathrm{x}=0$; $0,025 ; 0,05 ; 0,075 ;$ dan 0,1$)$ diukur luas permukaannya dengan metode adsorpsi-desorpsi $\mathrm{N}_{2}$. Metode dasar pengukuran luas permukaan suatu material berpori telah dipublikasikan oleh Stephen Brunauer, Paul Hugh Emmett, dan Edward Teller (1938). Pendekatan metode yang dilakukan oleh Brunauer, Emmet dan Teller (BET) adalah adsorpsi multilayer dengan gas yang inert. Salah satu gas yang digunakan sebagai adsorbat pada metode BET adalah gas nitrogen. Pada prinsipnya, material berpori bertindak sebagai adsorben dan gas nitrogen sebagai adsorbat. Tiap molekul gas nitrogen yang teradsorbsi dapat memberikan informasi tetang luas area material berpori tersebut. Hasil pengukuran luas permukaan dari masing-masing padatan ditampilkan pada Tabel 1.

Data hasil pengukuran dengan metode BET menunjukkan adanya pengaruh modifikasi doping logam $\mathrm{Cu}$ terhadap padatan hasil sintesis. Secara keseluruhan hasil modifikasi doping padatan menyebabkan peningkatan luas permukaan. Semakin tinggi nilai $\mathrm{x}$ padatan maka semakin tinggi luas permukaan padatan. Pada padatan $\mathrm{MgF}_{1,985} \mathrm{OH}_{0,015}$ didapatkan luas permukaan sebesar $30,358 \mathrm{~m}^{2} / \mathrm{g}$. Peningkatan luas permukaan padatan didapatkan pada padatan dengan nilai $\mathrm{x}=0,025$ hinggga $\mathrm{x}=0,05$ setelah itu terjadi penurunan pada padatan dengan nilai $\mathrm{x}=0,075$. Kenaikan luas permukaan padatan terjadi kembali pada padatan dengan nilai $\mathrm{x}=0,075-0,1$. Peningkatan luas permukaan pada padatan dengan nilai $\mathrm{x}=0,075-0,1$ dimungkinkan merupakan luas sebagian dari logam $\mathrm{Cu}$ yang melebihi kapasitas doping padatan.

\section{KESIMPULAN}

Berdasarkan data dan pembahasan yang telah dilakukan, dapat diambil kesimpulan bahwa padatan $\mathrm{MgF}_{1,985}(\mathrm{OH})_{0,015}$ dan $\mathrm{Mg}_{1-\mathrm{x}} \mathrm{Cu}_{\mathrm{x}} \mathrm{F}_{0,985}(\mathrm{OH})_{0,015}$ telah dapat disintesis melalui metode sol-gel. $\quad \mathrm{MgF}_{1,985}(\mathrm{OH})_{0,015}$ dan $\mathrm{Mg}_{1-\mathrm{x}} \mathrm{Cu}_{\mathrm{x}} \mathrm{F}_{0,985}(\mathrm{OH})_{0,015}$ diukur luas permukaan spesifik $\left(\mathrm{S}_{\mathrm{BET}}\right)$ dengan adsorpsi gas $\mathrm{N}_{2}$. Hasil pengukuran luas permukaan padatan yang diperoleh berkisar antara 30,358$42,812 \mathrm{~m}^{2} / \mathrm{g}$. Modifikasi doping padatan dengan logam $\mathrm{Cu}$ dapat meningkatkan luas permukaan padatan. Semakin tinggi nilai $\mathrm{x}$ pada padatan $\mathrm{Mg}_{1-\mathrm{x}} \mathrm{Cu}_{\mathrm{x}} \mathrm{F}_{0,985}(\mathrm{OH})_{0,015}$ maka semakin tinggi luas permukaan. Luas permukaan tertinggi didapatkan pada padatan dengan nilai $\mathrm{x}=0,05$ yakni $42,812 \mathrm{~m}^{2} / \mathrm{g}$.

\section{UCAPAN TERIMA KASIH}

Penulis menyampaikan terima kasih kepada Laboratorium Kimia Material dan Energi, Departemen Kimia FMIPA ITS, Dana Kerja Sama Penelitian Internasional dengan Humboldt-Universität zu Berlin, serta semua pihak yang turut membantu.

\section{DAFTAR PUSTAKA}

[1] I. R. Rachma, "Sintesis dan Difraktogram Mg1xCuxF0,66(OH)1,34 (x = 0;0,025; 0,05; 0,075; 0,1 dan 0,15)," J. Sains Dan Teknol, 2016.

[2] G. Scholz, C. Stosiek, M. Feist, and E. Kemnitz, "Magnesium Hydroxide Fluorides - New Materials with Adjustable Composition and Properties," Eur. J. Inorg. Chem., vol. 2012, no. 14, pp. 2337-2340, May 2012.

[3] F. Schüth, "General Principles for the Synthesis and Modification of Porous Materials," in Handbook of Porous Solids, F. Schüth, K. S. W. Sing, and J. Weitkamp, Eds. Weinheim, Jerman: Wiley-VCH Verlag GmbH, 2002, pp. 533666

[4] S. Célérier and F. Richard, "Promising heterogeneous catalytic systems based on metal fluorides and oxide hydroxide fluorides: A short review," Catal. Commun., vol. 67, pp. 26-30, Jul. 2015.

[5] C. Perego and P. Villa, "Catalyst preparation methods," Catal. Today, vol. 34, no. 3, pp. 281-305, 1997.

[6] K. Tanabe, T. Sumiyoshi, K. Shibata, T. Kiyoura, and J. Kitagawa, "A New Hypothesis Regarding the Surface Acidity of Binary Metal Oxides," Bull. Chem. Soc. Jpn., vol. 47, no. 5, pp. 1064-1066, May 1974.

[7] E. Kemnitz, Y. Zhu, and B. Adamczyk, "Enhanced Lewis acidity by aliovalent cation doping in metal fluorides," J. Fluor. Chem, 
vol. 114, no. 2, pp. 163-170, 2002

[8] S. Wuttke et al., "Novel Sol-Gel Synthesis of Acidic MgF2-x(OH)x Materials," Chem. - A Eur. J., vol. 14, no. 36, pp. 11488-11499, Dec. 2008.
[9] J. K. Murthy, U. Gross, S. Rüdiger, E. Ünveren, W. Unger, and E. Kemnitz, "Synthesis and characterization of chromium(III)doped magnesium fluoride catalysts," Appl. Catal. A Gen., vol. 282, no. 1, pp. 85-91, Mar. 2005. 